\section{Mini-implants: Alternative for Oral Rehabilitation of a Child with Ectodermal Dysplasia}

Bianca Zeponi Fernandes Mello1, Thiago Cruvinel Silva1, Daniela Rios¹, Maria Aparecida Andrade Moreira Machado', Fabrício Pinelli Valarelli², Thais Marchini Oliveira ${ }^{1}$

\author{
'Department of Pediatric Dentistry, \\ Orthodontics and Public Health, \\ Bauru Dental School, USP - University \\ of São Paulo, Bauru, SP, Brazil \\ ${ }^{2}$ Department of Orthodontics, Ingá \\ University, Maringá, PR, Brazil \\ Correspondence: Thais Marchini \\ Oliveira, Alameda Dr. Octávio \\ Pinheiro Brisolla, 9-75, 17012-901 \\ Bauru, SP, Brasil. Tel: +55-14-3235- \\ 8224. e-mail:marchini@usp.br
}

Ectodermal dysplasia is a rare congenital disease that affects several structures of ectodermal origin. The most commonly related oral characteristics are hypodontia, malformed teeth and underdeveloped alveolar ridges. New alternative treatments are needed due to the failure of the conventional prosthesis retention. This case report outlines the oral rehabilitation treatment of a 9-year-old girl with ectodermal dysplasia. The treatment was performed with conventional prosthesis upon mini-implants. The mini-implants provided prosthetic retention. The patient reported a good adaptation of the dental prosthesis and satisfaction with the treatment. The increased self-esteem improved the socialization skills of the girl. In this case report, use of prosthesis with mini-implants was satisfactory for prosthetic retention. However, clinical studies with long-term follow-up are needed to test the mini-implants as an alternative for oral rehabilitation of children with ectodermal dysplasia.
Key Words: ectodermal dysplasia, child, oral rehabilitation.

\section{Introduction}

Ectodermal dysplasia (ED) is a rare congenital disease linked to a recessive gene from $X$ chromosome. It affects several structures of ectodermal origin, such as hair, skin, nails and teeth. This disease has an incidence of $1: 100,000$ births, is more common among boys and has a $30 \%$ mortality rate in childhood due to intermittent hyperthermia (1-3).

The patient with ED presents specific facial and oral characteristics, such as saddled nose, decreased vertical dimension, facial depth, labial protuberance, little hair, lack of eyelashes and eyebrows, hypodontia, malformed and conical teeth, diastema, underdeveloped alveolar ridges, lack of teeth on both deciduous and permanent dentitions (4).

Dental prosthesis is the conventional oral rehabilitation of patients with ED. Due to the lack of areas for prosthesis retention and stability in these patients, some alternatives of rehabilitation are needed. Dental implants have been used as an alternative to increase the support or retention of definitive prostheses (5-8). Mini-implants, frequently used for orthodontic anchorage and prosthesis abutments, have been suggested as conventional implants with smaller dimensions. Patients treated with mini-implants as dental abutments demonstrated more satisfaction with their rehabilitation than those treated with conventional prostheses (9). The authors reported better retention and adaptation, and masticatory efficiency and comfort, resulting in a positive impact on their quality of life.
There are two reports on the use of mini-implants for prosthetic rehabilitation of children $(10,11)$ and recently, Sfeir et al. (12), described the use of mini-implants in children with ED.

This paper presents a case of oral rehabilitation of a child with ED using dental prosthesis supported by mini-implants.

\section{Case Report}

A 9-year-old girl presented with chief complaint of missing teeth and speech and mastication impairment. During review of clinical history, the mother reported that the child had been examined by a pediatrician and diagnosed with ED. History of lack of retention and stability of a previously used dental prosthesis was also reported.

Extraoral examination revealed visible loss of facial vertical dimension, hypotonicity of the perioral musculature, with a senile facial appearance. The patient presented dry and rough skin, sparse scalp hair, missing eyelashes and eyebrows, and severe hypohidrosis (Fig. 1A). Intraoral examination was observed hypodontia, with the presence of four erupted teeth (\#55, \#65, \#75 and \#85), and two conical teeth (\#11 and \#21) (Fig. 1B), besides reduced vertical dimension, xerostomia, and diastema between maxillary anterior teeth. Dental germs of the mandibular first molars were identified on the panoramic radiograph (Fig. 1C).

In the first treatment approach, the dentists had recommended the restoration of the maxillary incisors and adaptation of a conventional partial removable 
prosthesis. Due to the failure of the conventional prosthesis retention, a new treatment approach was suggested, which included mini-implant placement to support mandibular prosthesis. The mother was informed about the procedures involved in the fabrication of the dental prostheses and mini-implants. All procedures were carried out with the adequate understanding and written consent from mother (her legal guardian).

The maxillary anterior teeth were restored with composite resin prior to mini-implant placement. After an infiltrative terminal anaesthesia, a reference mark was performed on gingiva to guide the penetration of miniimplants (10 mm long, $2 \mathrm{~mm}$ transmucosal area and $1.6 \mathrm{~mm}$ diameter; Morelli, Sorocaba, SP, Brazil). Two mini-implants were placed in the correct position and inclination (Fig. 2). A functional modeling was performed for manufacturing the mandibular prosthesis. In a subsequent clinical session, the maxillary and mandibular prostheses were previously tested and adjusted in wax. On the next appointment, the mini-implants were covered by composite resin and the mandibular prosthesis was re-based with acrylic resin for improvement of the adaptation. Finishing and polishing were performed after the elimination of occlusal interferences. Following this, the mother and the child received instructions about oral hygiene and prosthesis placement. The patient reported a good adaptation of the dental prosthesis and satisfaction with the treatment. The increased self-esteem improved the socialization skills of the girl.

The mother was informed about the continuing re-evaluation and remaking of the dental prosthesis as the alveolar ridges and oral environment change due to growth. The patient is under continuous follow up for 6 months (Fig. 3).
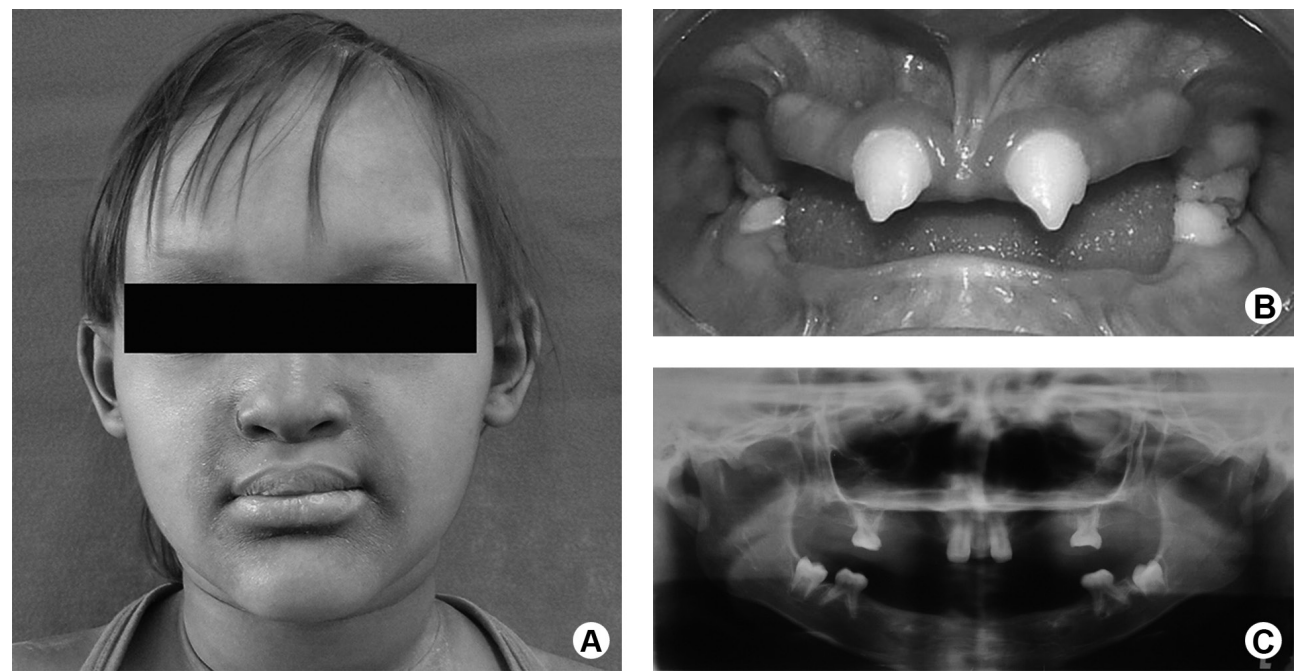

Figure 1. A: Patient with clinical characteristics of ectodermal dysplasia. B: Frontal intraoral view before oral rehabilitation. C: Panoramic radiograph showing the pattern of hypodontia in the mixed dentition.

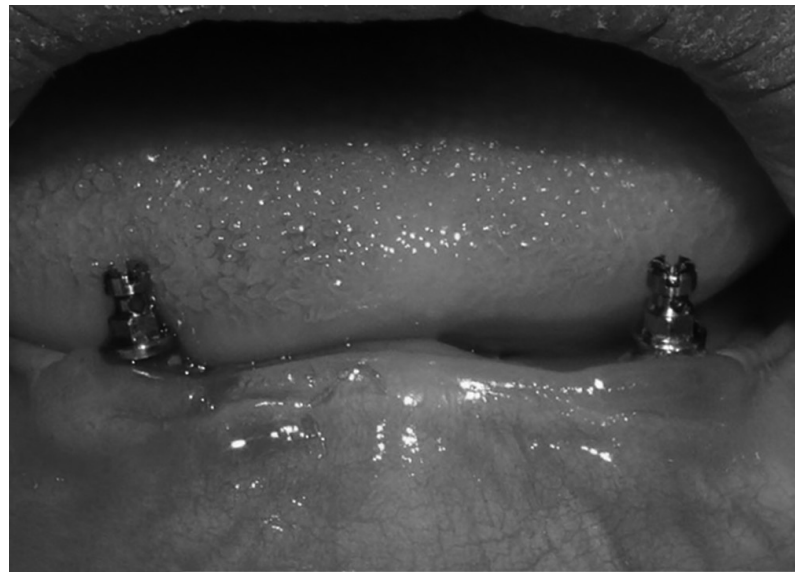

Figure 2. Intraoral view shwoing mini-implants soon after placement.

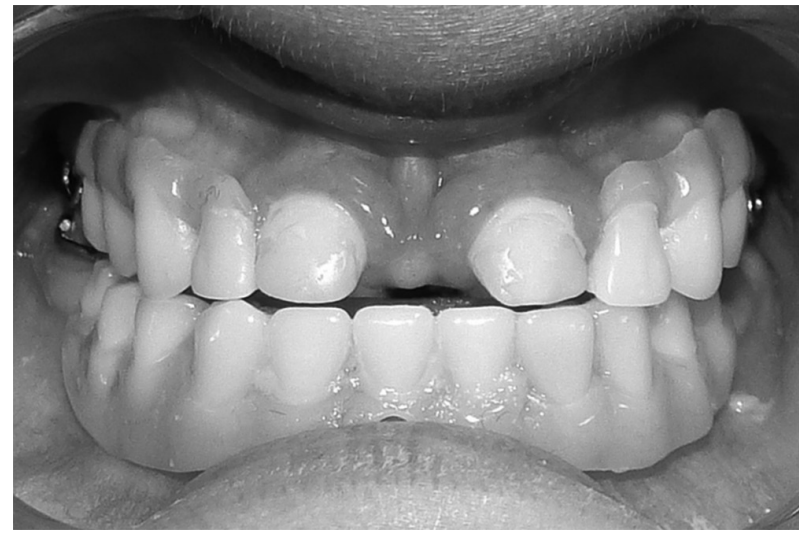

Figure 3. Prostheses and mini-implants after 6-month follow-up. 


\section{Discussion}

In the present case, the clinical characteristics of a patient with ED led to the challenge of searching alternative methods for oral rehabilitation, which must provide better functional and esthetic results. Patients with hypodontia and anodontia are frequently treated with total or partial conventional removable prosthesis $(13,14)$. Early rehabilitation improves masticatory efficiency, swallowing ability, phonetic capability and esthetics (14-19).

The patient of this case treated with intraosseous dental implants and fixed prosthesis showed absence of bone resorption in the symphysis area after a 6-year follow-up. However, long-term effects of the rehabilitation on the growth and the development of craniofacial structures were not considered. Bergendal et al. (20) demonstrated a frequent dental implant loss among patients with ectodermal dysplasia (64.3\%), unlike patients with dental trauma and agenesis treated with dental implants. Children with ED should be rehabilitated with smaller implants due to the reduced dimension of the maxillary and cortical bones. Sfeir et al. (12) presented three cases of children with ED where mini-implants were used for prostheses retention. The authors affirmed that the use of mini-implants should be part of the treatment in cases of ED and that their use reduce the number of surgeries required for conventional implants (12).

This treatment approach provided more comfortable rehabilitation and psychological benefits for the child, as demonstrated in a nother case report (21). However, our case presents a short-term follow-up. Further clinical evaluations must be performed each six months to observe the need of mini-implant replacements and/or substitution of prostheses due to the growth and development processes. There is not enough evidence on the ideal time for miniimplant placement and the minimum time required for monitoring $(12,22,23)$. The monitoring of conventional dental prostheses and implants varies between 3 and 12 months $(1,24,25)$.

In this case report, the dental prosthesis with miniimplants was satisfactory for prosthetic retention. The mini-implants allowed greater retention of prosthesis and a significant improvement in speech and mastication. However, clinical studies with long-term follow-up are needed to test the mini-implants as an alternative for oral rehabilitation of children with ectodermal dysplasia.

\section{Acknowledgements}

The authors wish to thank Luiz Sérgio Vieira for manufacturing the dental prostheses.

\section{Resumo}

A displasia ectodérmica é uma doença congênita rara, que afeta várias estruturas de origem ectodérmica. As principais caracteristicas na cavidade oral são hipodontia, má formação dentária e subdesenvolvimento do rebordo alveolar. Devido às falhas de retenção das próteses convencionais, novas alternativas de tratamento são necessárias. Este relato de caso descreve o tratamento de reabilitação oral em uma menina de 9 anos de idade com displasia ectodérmica. 0 tratamento foi realizado com próteses dentárias convencionais sobre mini-implantes. Os mini-implantes promoveram a retenção da prótese. A paciente relatou uma boa adaptação das próteses e satisfação com o tratamento. 0 aumento da autoestima melhorou as atividades de socialização da criança. Neste estudo de caso, o uso de prótese com mini-implantes foi satisfatória para a retenção da prótese. No entanto, estudos clínicos longitudinais são necessários para testar os mini-implantes como uma alternativa para a reabilitação oral de crianças com displasia ectodérmica.

\section{References}

1. Aydinbelge M, Gumus HO, Sekerci AE, Demetoglu U, Etoz OA. Implants in children with hypohidrotic ectodermal dysplasia: an alternative approach to esthetic management: case report and review of the literature. Pediatr Dent 2013;35:441-446.

2. Kere J, Srivastava AK, Montonen O, Zonana J, Thomas N, Ferguson $B$, et al.. X-linked anhidrotic (hypohidrotic) ectodermal dysplasia is caused by mutation in a novel transmembrane protein. Nat Genet 1996;13:409-416.

3. Ziada H, Holland T. Ectodermal dysplasia: a case report. J Ir Dent Assoc 1997;43:127-129.

4. Sakai T, Oliveira TM, Pessan JP, Santos CF, Machado MA. Alternative ora rehabilitation of children with hypodontia and conical tooth shape: a clinical report. Quintessence Int 2006;37:725-730.

5. Mankani N, Chowdhary R, Patil BA, Nagaraj E, Madalli P. Osseointegrated dental implants in growing children: a literature review. J Oral Implantol 2014;40:627-631.

6. Alcan T, Basa S, Kargul B. Growth analysis of a patient with ectodermal dysplasia treated with endosseous implants: 6-year follow-up. J Oral Rehabil 2006;33:175-182.

7. Bergendal B. Prosthetic habilitation of a young patient with hypohidrotic ectodermal dysplasia and oligodontia: a case report of 20 years of treatment. Int J Prosthodont 2001;14:471-479.

8. Johnson EL, Roberts MW, Guckes AD, Bailey L, Phillips CL, Wright JT. Analysis of craniofacial development in children with hypohidrotic ectodermal dysplasia. Am J Med Genet 2002;112:327-334.

9. Preoteasa $E_{1}$ Marin $M$, Imre $M$, Lerner $H_{1}$, Preoteasa CT. Patients' satisfaction with conventional dentures and mini implant anchored overdentures. Rev Med Chir Soc Med Nat lasi 2012;116:310-316.

10. Güler N, Cildir S, Iseri U, Sandalli N, Dilek O. Hypohidrotic ectodermal dysplasia with bilateral impacted teeth at the coronoid process: a case rehabilitated with mini dental implants. Oral Surg Oral Med Oral Pathol Oral Radiol Endod 2005;99:E34-E38.

11. Giannetti L, Murri Dello Diago A, Vecci F, Consolo U. Mini-implants in growing patients: a case report. Pediatr Dent 2010;32:239-244.

12. Sfeir $E$, Nassif $N$, Moukarzel C. Use of mini dental implants in ectodermal dysplasia children: follow-up of three cases. Eur J Paediatr Dent 2014;15:207-212.

13. Paul ST, Tandon S, Kiran M. Prosthetic rehabilitation of a child with induced anodontia. J Clin Pediatr Dent 1995;20:5-8.

14. Pettit S, Campbell PR. Ectrodactyly-ectodermal dysplasia-clefting syndrome: the oral hygiene management of a patient with EEC. Spec Care Dentist 2010;30:250-254.

15. Al-Ibrahim HA, Al-Hadlaq SM, Abduljabbar TS, Al-Hamdan KS, Abdin HA. Surgical and implant-supported fixed prosthetic treatment of a patient with ectodermal dysplasia: a case report. Spec Care Dentist 2012;32:1-5.

16. Derbanne MA, Sitbon MC, Landru MM, Naveau A. Case report: Early prosthetic treatment in children with ectodermal dysplasia. Eur Arch Paediatr Dent 2010;11:301-305.

17. Kohli R, Levy S, Kummet CM, Dawson DV, Stanford CM. Comparison of perceptions of oral health-related quality of life in adolescents 
affected with ectodermal dysplasias relative to caregivers. Spec Care Dentist 2011;31:88-94.

18. Sholapurkar AA, Setty S, Pai KM. Total anodontia in patient with hypohidrotic ectodermal dysplasia. Report of rare case of ChristSiemens Touraine syndrome. N Y State Dent J 2011;77:36-39.

19. Vieira KA, Teixeira MS, Guirado CG, Gaviao MB. Prosthodontic treatment of hypohidrotic ectodermal dysplasia with complete anodontia: case report. Quintessence Int 2007;38:75-80.

20. Bergendal B, Ekman A, Nilsson P. Implant failure in young children with ectodermal dysplasia: A retrospective evaluation of use and outcome of dental implant treatment in children in Sweden. Int J Oral Maxillofac Implants 2008;23:520-524.

21. Bulut $E$, Guler AU, Sen Tunc E, Telcioglu NT. Oral rehabilitation with endosseous implants in a child with ectodermal dysplasia: a case report. Eur J Paediatr Dent 2010;11:149-152.
22. Bidra AS, Almas K. Mini implants for definitive prosthodontic treatment: a systematic review. J Prosthet Dent 2013;109:156-164.

23. Mishra SK, Chowdhary N, Chowdhary R. Dental implants in growing children. J Indian Soc Pedod Prev Dent 2013;31:3-9.

24. Vallejo AP, Monje ELA, Garcia MG, Fernandez MM, Buylla FBMA. Treatment with removable prosthesis in hypohidrotic ectodermal dysplasia. A clinical case. Med Oral Patol Oral Cir Bucal 2008 1;13:E119-E123.

25. Marques NCT, Gurgel CV, Fernandes AP, Lima MC, Machado MA, Soares $S$, et al.. Prosthetic rehabilitation in children: an alternative clinical technique. Case Rep Dent 2013;2013:512951.

Received May 30, 2014 Accepted November 27, 2014 